\title{
Impact of Citharexylum Quadrangular Chloroform Extract and Micronutrient on Praziquantel in Schistosoma Mansoni Infected Mice
}

\author{
Ebtehal M. Farrag' ${ }^{1}$, Azza M. Mohamed ${ }^{1,2}$, Shadia M. Kadry ${ }^{3}$, Ahlam H. Mahmoud ${ }^{1,4, ~ *}$, \\ Abdel-Razik H. Farrag ${ }^{5}$, Dalia B. Fayed ${ }^{1}$ \\ ${ }^{1}$ Therapeutic Chemistry Department, National Research Center, Dokki, Egypt \\ ${ }^{2}$ Biochemistry Department, Faculty of Science for Girl's, King Abdulaziz University, Jeddah, Kingdom of Saudi Arabia \\ ${ }^{3}$ Zoology Department, Women's College for Arts, Science and Education, Ain Shams University, Cairo, Egypt \\ ${ }^{4}$ Biology Department, Faculty of Science for Girl's, Jazan University, Jazan, Kingdom of Saudi Arabia \\ ${ }^{5}$ Pathology Department, National Research Center, Dokki, Egypt \\ Email address: \\ ahlamhosnynrc@gmail.com (A. H. Mahmoud)
}

\section{To cite this article:}

Ebtehal M. Farrag, Azza M. Mohamed, Shadia M. Kadry, Ahlam H. Mahmoud, Abdel-Razik H. Farrag, Dalia B. Fayed. Impact of Citharexylum Quadrangular Chloroform Extract and Micronutrient on Praziquantel in Schistosoma Mansoni Infected Mice. American Journal of Life Sciences. Vol. 3, No. 2, 2015, pp. 62-70. doi: 10.11648/j.ajls.20150302.12

\begin{abstract}
Praziquantel (PZQ), the drug of choice according to the World Health Organization (WHO), causes some side effects. The appearance of drug resistance against PZQ in Schistosoma mansoni infected species leads to must introduce new effective compounds and/or suppress its side effects. The aim of present work is a trial to solve this problem. Chloroform extract of Citharexylum quadrangular jacq leaves was used as a medicinal plant, which affect the Schistosoma mansoni adults. Prophylactic and therapeutic treatment of Schistosoma mansoni infected mice with the plant extract and/or the antioxidants vitamin $\mathrm{E}$ and selenium in combination with PZQ was studied. The study revealed that the combination of the chloroform extract together with vitamin E and selenium improved the efficiency of PZQ. These supplementations are very effective in ameliorating the oxidative insult as well as other parameters: glutathione reductase (GR), thioredoxin reductase (TrxR), catalase (CAT) and reduced glutathione (GSH), nitric oxide (NO) and lipid peroxidation (MDA), hepatic hydroxyproline content, Alanine aminotransferase (ALT), Gamma-glutamyltransferase $(\gamma$-GT), tumor necrosis factor-alpha (TNF $\alpha$ ), interleukin- 10 (IL-10) and total immunoglobulin E (total IgE) associated with Schistosoma mansoni infection.
\end{abstract}

Keywords: Schistosoma Mansoni- Chloroform Extract of Citharexylum Quadrangular Leaves- Micronutrients

\section{Introduction}

Schistosomiasis is a notable neglected tropical disease caused by trematodes that inflame mainly the intestines, bladder, and liver. Because of the unavailability of a schistosomiasis vaccine, control of the disease depends mainly on chemotherapy. Praziquantel (PZQ), which is active against all schistosome species and the recommended drug by the World Health Organization (WHO) for schistosomiasis treatment at either the community or individual level, has become the exclusive drug because of its low cost and efficacy against the adult form of all schistosome species [1]. There are emerging problems with praziquantel treatment, which include the appearance of drug resistance in the treatment of
Schistosoma mansoni and possibly Schistosoma japonicum, along with allergic or hypersensitivity reactions against praziquantel treatment [2]. Histopathological examination of some patients showed the presence of viable eggs and granulomas in the productive phase post-treatment with PZQ [3]. To cope with and overcome these problems, combined use of drugs, i.e., praziquantel and other newly introduced compounds such as triclabendazole, artemisinins, and tribendimidine, is being tried [2].

The objective of the present study is a trial to improve the efficiency of PZQ and decrease its side effects, by using some micronutrients vitamin $\mathrm{E}$ (Vit $\mathrm{E}$ ) and selenium (Se) and chloroform extract of Citharexylum quadrangular Jacq leaves. This was achieved through prophylactic and therapeutic treatments of S. mansoni infected mice with these agents in 
combination with PZQ compared with treatment of PZQ only.

\section{Materials and Methods}

\subsection{Chemicals}

All chemicals used were of high analytical grade, products of Fluka, Sigma and Aldrich Co. (St. Louis, MO, USA).

\subsection{Plant Collection and Extraction}

Leaves of C. quadrangular Jacq (family: Verbenaceae) were collected (April, 2009) from the Zoo, Giza, Egypt. It was identified by Mr. Mahmoud Yosery, General Manager and Head of Specialists of Plant Taxonomy, Giza Zoo, Egypt.

The dried powdered leaves were extracted exhaustively in a Soxhlet apparatus using the following successive solvents with increasing polarities: Petroleum ether $\left(40-60^{\circ} \mathrm{C}\right)$ followed by chloroform. After complete extraction, the chloroform solvent was evaporated to dryness under vacuum at $40^{\circ} \mathrm{C}$ yielding semisolid free chloroform extract residue.

\subsection{Animals and Toxicity of Tested Plant Extract}

Swiss albino female mice CDI strain (18-22 g) were selected and maintained throughout the experiment in the Schistosome Biological Materials Supply Program, Theodor Bilharz Research Institute (SBSP/TBRI), Giza, Egypt. Mice were kept in a controlled environment of air and temperature with access to diet and water ad libitum.

Thirty six mice were divided into 6 groups ( 6 mice each) for determination of chloroform extract of $\mathrm{C}$. quadrangular leaves safety. Six doses $(500-5000 \mathrm{mg} / \mathrm{Kg})$ were suspended in corn oil and orally administrated to mice. 24 hours post oral administration, numbers of dead animals were counted and the mortality rate was calculated. No dead mice were recorded up to $5000 \mathrm{mg} / \mathrm{kg}$ body weight (B.wt) revealing extract safety.

\subsection{Experimental Design}

Hundred and ten normal female mice were divided into eleven equal groups.

Group 1: served as normal healthy animals.

Groups 2: S. mansoni infected mice.

Groups 3: S. mansoni infected mice treated with PZQ (500 $\mathrm{mg} / \mathrm{Kg}$ B.wt /day) for two consecutive days [4] (6 weeks post infection).

Group 4 to 7: (Prophylactic groups) Animals supplemented with Vit E $(100 \mathrm{mg} / \mathrm{Kg}$ B.wt), Se $(200 \mu \mathrm{g} / \mathrm{Kg}$ B.wt $)$ [5], chloroform extract of C. quadrangular leaves $(500 \mathrm{mg} / \mathrm{Kg}$ B.wt/day) or the mixture of all of these supplements respectively for four weeks before infection and along with the experimental period after the infection and treated with PZQ for two consecutive days (6 weeks post infection).

Group 8 to 11: (Therapeutic groups) S. mansoni infected mice reached mature steps were treated with the different studied supplements in combination with PZQ. The different supplements were given orally for two weeks, while PZQ was ingested only for two consecutive days.

\subsection{Biological Studies}

\subsubsection{Parasites and Infection}

Cercariae of S. mansoni Egyptian strain were obtained from SBSP/TBRI and used for infection immediately after shedding from Biomphalaria alexandrina snails. Infection was carried out with $75 \pm 5 \mathrm{~S}$. mansoni cercariae/ mouse by subcutaneous injection [6].

\subsubsection{Liver Perfusion}

At the end of the experimental period ( 8 weeks post infection), mice were euthanized by decapitation. Worms were recovered from the hepatic portal system by perfusion technique [7]. The worms from each mouse were left to sediment for about $20 \mathrm{~min}$ in a small Petri dish and counted under light microscope. The degree of protection or the \% of reduction after challenge was calculated as follows: $\mathrm{P}=\mathrm{C}$ $\mathrm{V} / \mathrm{C} \times 100$, where $\mathrm{P}$ is the $\%$ protection, $\mathrm{C}$ is the mean number of the parasites recovered from untreated infected mice and $\mathrm{V}$ is the mean number of the parasites recovered from treated infected mice.

\subsubsection{Tissue Egg Load}

The number of eggs/g tissue (liver and intestine) was assessed following digestion with $4 \% \mathrm{KOH}$ according to Kamel et al. [8].

\subsection{Histopathology and Granuloma Measurements}

Representative slices from liver tissue were taken from the eviscerated animals and fixed in buffered formalin (10\%). Paraffin embedded sections ( $4 \mu \mathrm{m}$ thick) were taken after fixation and slides were stained using hematoxlin and eosin (H\& E) by the method of Hirsch et al. [9]. Counting of granulomas was carried out according to Mahmoud and Warren [10].

\subsection{Biochemical Studies}

The blood of sacrificed mice was collected and serum was separated by centrifugation at 3000 r.p.m for 10 minutes at $4^{\circ} \mathrm{C}$ and stored at $-80^{\circ} \mathrm{C}$ for further biochemical determinations.

After liver perfusion, livers from different animal groups were immediately removed, weighed and washed using saline solution. The liver tissues were minced and homogenized in either $10 \%$ trichloro-acetic acid for NO and MDA determinations or in ice cold bidistilled water for hydroxyproline, GR, TrxR, CAT and GSH determinations to yield $10 \%$ homogenate using a glass homogenizer. The homogenates were centrifuged for 15 minutes at $3000 \times \mathrm{g}$ at $4^{\circ} \mathrm{C}$ and the supernatants were stored at $-80^{\circ} \mathrm{C}$ for further biochemical analysis.

\subsubsection{Tissue Biochemical Analysis}

The levels of antioxidant markers: GR [11], TrxR[12], CAT [13] and GSH [14] were estimated in the liver tissue homogenates of the tested and control groups. The hepatic hydroxyproline content [15], NO [16] and MDA [17] were measured in livers of different experimental groups. 


\subsubsection{Serum Biochemical Analysis}

Alanine aminotransferase (ALT) was measured using kit purchased from Greiner Diagnostic GmbH (Germany). Gamma-glutamyltransferase ( $\gamma$ - GT) was determined using kit purchased from SPINREACT (Spain). Albumin was measured using kit purchased from Diamond Diagnostic (Egypt). Enzyme linked immunosorbent assay (ELISA) procedure was used for quantitative determination of mouse tumor necrosis factor-alpha (TNF $\alpha)$, interleukin- 10 (IL-10) and total immunoglobulin E (total IgE) using kit purchased from Thermo Scientific (USA) and Shibayagi (Japan), respectively.

\subsubsection{Statistical Analysis}

The results were presented as mean \pm standard deviation (S.D.) of 10 mice in each group. Results were analyzed statistically by one way analysis of variance (ANOVA) using SPSS (Statistical Package for the Social Sciences, version 9) software followed by post-hoc test at least significance difference between groups at $\mathrm{p} \leq 0.05$.

\subsubsection{Ethics}

This study was conducted in accordance with legal ethical guidelines of the Medical Ethical Committee of the National Research Center, Dokki, Egypt (approval no. 09210).

\section{Results}

\subsection{Oral Safety Study}

No mortality or clinical signs of toxicity were observed on administration of chloroform extract of C. quadrangular leaves to normal healthy mice on using doses up to $5000 \mathrm{mg} / \mathrm{Kg}$ body weight after 24 hours of plant extract ingestion.

\subsection{Effect of Different Supplements}

\subsubsection{Effect on Parasitological Parameters}

Treatment of S. mansoni infected mice with PZQ only showed a significant reduction in total worm burden as well as in total egg burden collected from liver and intestine when compared to infected untreated mice $(\mathrm{P} \leq 0.05)$ (table 1$)$. Prophylactic and therapeutic ingestion of either of vitamin E, Se, plant extract or the mixture of all agents together with PZQ showed hundred percent reductions against total worm burden. Also, the effect of PZQ in combination with different supplements (Vit E, Se, plant extract and the mixture of all supplements) improved the ova count by $(82.4,88.77,91.22$ \& 94.8\% respectively) in prophylactic treatment and (79.54, $82.55,86.13 \& 89.29 \%$ respectively) in therapeutic treatment with respect to infected untreated mice. Also, a reduction in granuloma number and its diameter (table 1) was obtained in these groups. The therapeutic treatment of infected mice with Vit E, Se and the mixture of all supplements in combination with PZQ revealed no significant improvement in granuloma count versus the group treated with PZQ only. Vit E, Se and plant extract in combination with PZQ were less effective than PZQ only against granuloma diameter. The best results were obtained in case of the prophylactic treatment of the studied agents in combination with PZQ.

Table 1. Prophylactic and therapeutic effect of different supplementations on parasitological parameters

\begin{tabular}{llllll|l|l|l|l}
\hline \multirow{2}{*}{$\begin{array}{lllll}\text { Parameter } \\
\text { Animals gps }\end{array}$} & \begin{tabular}{l} 
Total worm burden \\
\cline { 2 - 8 }
\end{tabular} & $\begin{array}{l}\text { Prophylactic } \\
\text { groups }\end{array}$ & $\begin{array}{l}\text { Therapeutic } \\
\text { groups }\end{array}$ & $\begin{array}{l}\text { Prophylactic } \\
\text { groups }\end{array}$ & $\begin{array}{l}\text { Therapeutic } \\
\text { groups }\end{array}$ & $\begin{array}{l}\text { Prophylactic } \\
\text { groups }\end{array}$ & $\begin{array}{l}\text { Therapeutic } \\
\text { groups }\end{array}$ & $\begin{array}{l}\text { Prophylactic } \\
\text { groups }\end{array}$ & $\begin{array}{l}\text { Therapeutic } \\
\text { groups }\end{array}$ \\
\hline Infected untreated & $38.80 \pm 4.51$ & $36.80 \pm 5.79$ & $43489 \pm 91$ & $43464 \pm 276$ & $7.31 \pm 0.97$ & $7.37 \pm 1.09$ & $227.82 \pm 16.6$ & $232.37 \pm 9.27$ \\
PZQ & $1.25 \pm 1.03^{\mathrm{b}}$ & $0.60 \pm 0.88^{\mathrm{b}}$ & $8910 \pm 606^{\mathrm{b}}$ & $8899 \pm 641^{\mathrm{b}}$ & $4.76 \pm 0.99^{\mathrm{b}}$ & $4.74 \pm 1.13^{\mathrm{b}}$ & $159.73 \pm 18.38^{\mathrm{b}}$ & $153.73 \pm 17.4^{\mathrm{b}}$ \\
Reduction \% & 96.77 & 98.36 & 79.51 & 79.52 & 34.88 & 35.68 & 29.88 & 33.84 \\
Vit. E + PZQ & $0^{\mathrm{b}}$ & $0^{\mathrm{b}}$ & $7651 \pm 523^{\mathrm{bc}}$ & $8891 \pm 813^{\mathrm{b}}$ & $3.49 \pm 1.07^{\mathrm{bc}}$ & $3.72 \pm 0.75^{\mathrm{b}}$ & $149.86 \pm 4^{\mathrm{b}}$ & $184.41 \pm 15.2^{\mathrm{bc}}$ \\
Reduction \% & 100 & 100 & 82.4 & 79.54 & 52.25 & 49.52 & 34.21 & 20.63 \\
Se+ PZQ & $0^{\mathrm{b}}$ & $0^{\mathrm{b}}$ & $4880 \pm 588^{\mathrm{bc}}$ & $7581 \pm 693^{\mathrm{bc}}$ & $2.67 \pm .82^{\mathrm{bc}}$ & $4.62 \pm 1.23^{\mathrm{b}}$ & $118.18 \pm 6.22^{\mathrm{bc}}$ & $183.63 \pm 10.9^{\mathrm{bc}}$ \\
Reduction \% & 100 & 100 & 88.77 & 82.55 & 66.89 & 37.31 & 48.12 & 20.97 \\
Plant extract + PZQ & $0^{\mathrm{b}}$ & $0^{\mathrm{b}}$ & $3818 \pm 465^{\mathrm{bc}}$ & $6025 \pm 832^{\mathrm{bc}}$ & $2.45 \pm 0.21^{\mathrm{bc}}$ & $3.43 \pm 1.15^{\mathrm{bc}}$ & $122.53 \pm 4.36^{\mathrm{bc}}$ & $163.79 \pm 8.06^{\mathrm{b}}$ \\
Reduction \% & 100 & 100 & 91.22 & 86.13 & 66.48 & 53.45 & 46.21 & 29.51 \\
Mixture + PZQ & $0^{\mathrm{b}}$ & $0^{\mathrm{b}}$ & $2258 \pm 147^{\mathrm{bc}}$ & $4653 \pm 490^{\mathrm{bc}}$ & $2.33 \pm 0.72^{\mathrm{bc}}$ & $4.28 \pm 1.13^{\mathrm{b}}$ & $108.12 \pm 4.09^{\mathrm{bc}}$ & $120 \pm 7.71^{\mathrm{bc}}$ \\
Reduction \% & 100 & 100 & 94.8 & 89.29 & 69.9 & 41.92 & 52.54 & 48.34 \\
\hline
\end{tabular}

Data are expressed as mean $\pm \mathrm{SD}$ of 10 mice in each group. (b) is the level of significance at $P \leq 0.05$ compared with infected untreated group. (c) is the level of significance at $P \leq 0.05$ compared with PZQ treated group.

\subsubsection{Effect on Liver Histopathology}

S. mansoni infected liver showed large granuloma and excess inflammation cells (Fig. 1b) compared to normal liver section (Fig. 1a). The therapeutic effect of PZQ only recorded reduction of granuloma area, modulating size of granuloma with a trapped or disintegrating central Schistosoma eggs (Figs. 1c). Prophylactic and therapeutic treatments with the investigated supplements in combination with PZQ treatment improved the liver picture when compared with the infected untreated mice (Figs. 1d, e, f, g, h, i, j \& k). 

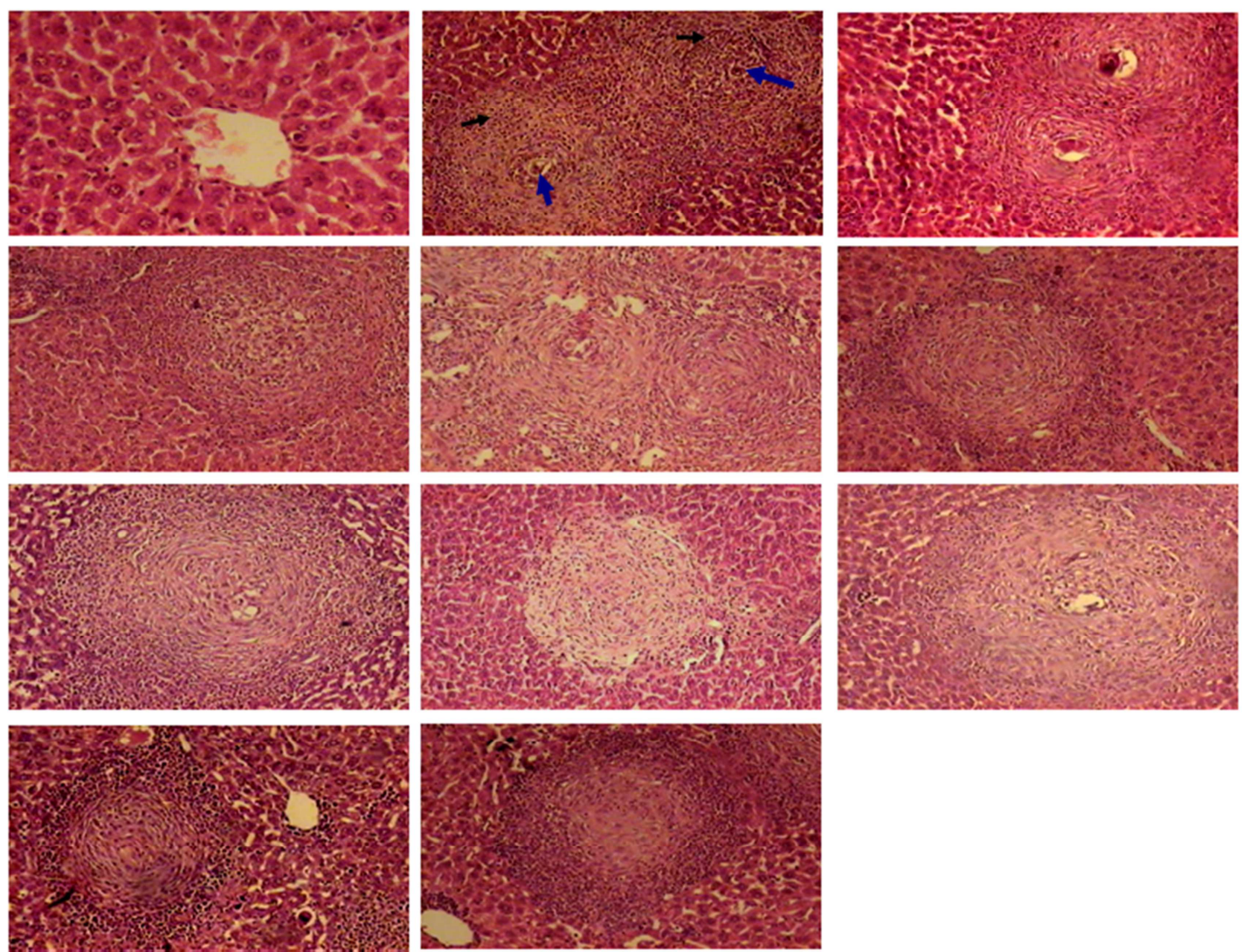

Fig. 1. Photomicrograph of liver sections. (a) Normal liver; (b) infected, exhibiting large granuloma with excess inflammatory cells and central schistosome egg; (c) PZQ treated group showing reduction of granuloma size with disintegrated centeral egg (d) prophylactic Vit. E $+P Z Q$ treated liver showing reduction of granuloma; (e) therapeutically Vit. E+PZQ group showing reduction of granuloma with disintegration of egg; (f) prophylactic Se+PZQ treated liver showing reduction of granuloma size and accumulation of inflammatory cells; $(g)$ therapeutically $S e+P Z Q$ treated mouse exhibiting granuloma with disintegrated egg; (h) prophylactic plant extract treated group showing reduction of granuloma area; (i) therapeutically plant extract treated liver exhibiting granuloma with disintegrated egg and a moderate accumulation of eosinophils in the centre; (j) prophylactic group treated with the mixture of all agents showing reduction granuloma and a marked infiltration of lymphocytes; $(k)$ therapeutic treated groups with the mixture of all supplementations showing reduction in granuloma size and accumulation of inflammatory cells.

\subsubsection{Effect on Liver Biochemical Parameters}

Infection with $\mathrm{S}$. mansoni recorded a marked decrease in the levels of hepatic enzymatic antioxidants; GR, TrxR, CAT $(\mathrm{P} \leq 0.05)$ compared to control groups. The decrease in GR was associated with a decrease in hepatic non-enzymatic antioxidant, GSH (table 2). The treatment of infected mice with PZQ showed an improvement in the studied parameters when compared to infected untreated group ( $\mathrm{P} \leq 0.05)$. Prophylactic or therapeutic treatment with the current agents in combination with PZQ markedly increased the antioxidant levels as compared to infected animals. All supplements either in prophylactic or in therapeutic groups enhanced the improvement of enzymatic hepatic antioxidant when compared to group treated with PZQ alone (table 2).

Table 2. Prophylactic and therapeutic effect of different supplementations on the levels of hepatic antioxidant markers

\begin{tabular}{|c|c|c|c|c|c|c|c|c|}
\hline \multirow[b]{2}{*}{$\begin{array}{l}\text { Parameter } \\
\text { Animals gps }\end{array}$} & \multicolumn{2}{|c|}{ GR (nmol/min/mg protein) } & \multicolumn{2}{|c|}{$\operatorname{TrxR}(\mu \mathrm{mol} / \mathrm{min} / \mathrm{mg}$ protein) } & \multicolumn{2}{|c|}{ CAT $(\mu \mathrm{mol} / \mathrm{min} / \mathrm{mg}$ protein) } & \multicolumn{2}{|c|}{ GSH $(\mu \mathrm{mol} / \mathrm{g}$ tissue $)$} \\
\hline & $\begin{array}{l}\text { Prophylactic } \\
\text { groups }\end{array}$ & $\begin{array}{l}\text { Therapeutic } \\
\text { groups }\end{array}$ & $\begin{array}{l}\text { Prophylactic } \\
\text { groups }\end{array}$ & $\begin{array}{l}\text { Therapeutic } \\
\text { groups }\end{array}$ & $\begin{array}{l}\text { Prophylactic } \\
\text { groups }\end{array}$ & $\begin{array}{l}\text { Therapeutic } \\
\text { groups }\end{array}$ & $\begin{array}{l}\text { Prophylactic } \\
\text { groups }\end{array}$ & $\begin{array}{l}\text { Therapeutic } \\
\text { groups }\end{array}$ \\
\hline Clean control & $91 \pm 1.93$ & $90.4 \pm 2.77$ & $37.27 \pm 2.22$ & $36.49 \pm 3.68$ & $19.39 \pm 1.62$ & $18.88 \pm 1$ & $10.11 \pm 1$ & $9.82 \pm 0.69$ \\
\hline Infected untreated & $41.91 \pm 2.02^{\mathrm{a}}$ & $42.26 \pm 3.33^{\mathrm{a}}$ & $10.38 \pm 1.5^{\mathrm{a}}$ & $9.57 \pm 1.67^{\mathrm{a}}$ & $7.27 \pm 1.13^{\mathrm{a}}$ & $6.1 \pm 0.7^{\mathrm{a}}$ & $3.55 \pm 0.59^{\mathrm{a}}$ & $3.47 \pm 0.4^{\mathrm{a}}$ \\
\hline PZQ & $71.58 \pm 1.44^{\mathrm{ab}}$ & $71 \pm 1.81^{\mathrm{ab}}$ & $22.15 \pm 1.23^{\mathrm{ab}}$ & $21.53 \pm 1.17^{\mathrm{ab}}$ & $12.36 \pm 1.54^{\mathrm{ab}}$ & $11.6 \pm 1.06^{\mathrm{ab}}$ & $5.8 \pm 0.6^{\mathrm{ab}}$ & $5.73 \pm 0.42^{\mathrm{ab}}$ \\
\hline Vit. E + PZQ & $80.04 \pm 2.76^{\mathrm{abc}}$ & $76.53 \pm 3.17^{\mathrm{abc}}$ & $25.69 \pm 1.68^{\mathrm{abc}}$ & $25.62 \pm 1.11^{\mathrm{abc}}$ & $15.68 \pm 1.38^{\mathrm{abc}}$ & $13.13 \pm 1.2^{\mathrm{abc}}$ & $6.13 \pm 0.31^{\mathrm{ab}}$ & $5.88 \pm 0.66^{\mathrm{ab}}$ \\
\hline $\mathrm{Se}+\mathrm{PZQ}$ & $84.95 \pm 3.06^{\mathrm{abc}}$ & $83.86 \pm 3.11^{\mathrm{abc}}$ & $28.13 \pm 0.89^{\mathrm{abc}}$ & $25.47 \pm 1.99^{\mathrm{abc}}$ & $14.37 \pm 1.23^{\mathrm{abc}}$ & $12.84 \pm 0.98^{\mathrm{abc}}$ & $6.13 \pm 0.37^{\mathrm{ab}}$ & $5.4 \pm 0.39^{\mathrm{ab}}$ \\
\hline Plant extract $+\mathrm{PZQ}$ & $86.35 \pm 2.03^{\mathrm{abc}}$ & $85.02 \pm 2.34^{\mathrm{abc}}$ & $31.75 \pm 1.7^{\mathrm{abc}}$ & $29.73 \pm 2.39^{\mathrm{abc}}$ & $14.76 \pm 1.42^{\mathrm{abc}}$ & $13.42 \pm 0.58^{\mathrm{abc}}$ & $6.42 \pm 0.43^{\mathrm{abc}}$ & $6.18 \pm 0.63^{\mathrm{ab}}$ \\
\hline Mixture + PZQ & $88.68 \pm 3.17^{\mathrm{bc}}$ & $86.53 \pm 2.06^{\text {abc }}$ & $35.18 \pm 2.79^{\mathrm{abc}}$ & $31.85 \pm 1.62^{\mathrm{abc}}$ & $16.53 \pm 1.38^{\mathrm{abc}}$ & $14.95 \pm 1.04^{\mathrm{abc}}$ & $7.76 \pm 0.49^{\mathrm{abc}}$ & $6.63 \pm 0.39^{\mathrm{ab}}$ \\
\hline
\end{tabular}

Data are expressed as mean $\pm \mathrm{SD}$ of 10 mice in each group. (a) is the level of significance at $P \leq 0.05$ compared with control group. (b) is the level of significance at $P \leq 0.05$ compared with infected untreated group. (c) is the level of significance at $P \leq 0.05$ compared with PZQ treated group.

The results revealed that infection with S. mansoni led to significant elevation of liver hydroxyproline when compared to normal uninfected mice (table 3). Also the present data revealed that animals treated with PZQ only showed a 
significant improvement in hydroxyproline content compared with infected untreated animals. Different prophylactic and therapeutic treatments with different supplementats in combination with PZQ induced a significant improvement in hydroxyproline content when compared to infected untreated mice. No great change was found in the level of hydroxyproline between the groups treated prophylactically nor therapeutically with either of the agents in combination with PZQ and the group treated with PZQ alone.

Regarding to NO and MDA content, S. mansoni infection induced elevation in their levels as compared with normal mice (table 3). Administration of PZQ only or with the investigated supplements successfully ameliorated the deviation in these markers compared to infected animals.

Table 3. Prophylactic and therapeutic effect of different supplementations on the levels of hepatic hydroxyproline and hepatic oxidative stress markers

\begin{tabular}{lllllll}
\hline \multirow{2}{*}{ Animals gps } & Parameter & \multicolumn{2}{l}{ Hydroxyproline $(\mu \mathrm{g} / \mathrm{g}$ liver tissue) } & \multicolumn{2}{l}{ NO $(\boldsymbol{\mu g} / \mathbf{g}$ liver tissue) } & \multicolumn{2}{l}{ MDA (nmol / g liver tissue) } \\
\cline { 2 - 7 } & $\begin{array}{l}\text { Prophylactic } \\
\text { groups }\end{array}$ & $\begin{array}{l}\text { Therapeutic } \\
\text { groups }\end{array}$ & $\begin{array}{l}\text { Prophylactic } \\
\text { groups }\end{array}$ & $\begin{array}{l}\text { Therapeutic } \\
\text { groups }\end{array}$ & $\begin{array}{l}\text { Prophylactic } \\
\text { groups }\end{array}$ & $\begin{array}{l}\text { Therapeutic } \\
\text { groups }\end{array}$ \\
\hline Clean control & $185.13 \pm 11.6$ & $182.75 \pm 9.81$ & $16.54 \pm 1.2$ & $16.16 \pm 0.77$ & $20.66 \pm 2.42$ & $20.37 \pm 2.26$ \\
Infected untreated & $648.23 \pm 54.04^{\mathrm{a}}$ & $656.39 \pm 49.03^{\mathrm{a}}$ & $76.79 \pm 2.86^{\mathrm{a}}$ & $78.02 \pm 3.54^{\mathrm{a}}$ & $54.56 \pm 1.63^{\mathrm{a}}$ & $55.55 \pm 1.59^{\mathrm{a}}$ \\
PZQ & $282.61 \pm 22.92^{\mathrm{ab}}$ & $283.12 \pm 16.45^{\mathrm{ab}}$ & $36.71 \pm 1.38^{\mathrm{ab}}$ & $37.24 \pm 1.12^{\mathrm{ab}}$ & $32.92 \pm 1.79^{\mathrm{ab}}$ & $33.85 \pm 1.45^{\mathrm{ab}}$ \\
Vit. E + PZQ & $266.27 \pm 27.6^{\mathrm{ab}}$ & $281.76 \pm 33.83^{\mathrm{ab}}$ & $36.61 \pm 2.5^{\mathrm{ab}}$ & $42.54 \pm 0.85^{\mathrm{abc}}$ & $31.34 \pm 1.65^{\mathrm{ab}}$ & $35.9 \pm 0.60^{\mathrm{abc}}$ \\
Se + PZQ & $277.72 \pm 19.73^{\mathrm{ab}}$ & $289.72 \pm 17.82^{\mathrm{ab}}$ & $35.36 \pm 1.87^{\mathrm{ab}}$ & $41.31 \pm 2.32^{\mathrm{abc}}$ & $32.74 \pm 1.74^{\mathrm{ab}}$ & $31.98 \pm 1.12^{\mathrm{abc}}$ \\
Plant extract + PZQ & $257.55 \pm 11.27^{\mathrm{ab}}$ & $273.65 \pm 10.74^{\mathrm{ab}}$ & $30.12 \pm 2.32^{\mathrm{abc}}$ & $36.63 \pm 2.11^{\mathrm{ab}}$ & $28.06 \pm 1.84^{\mathrm{abc}}$ & $31.46 \pm 1.18^{\mathrm{abc}}$ \\
Mixture + PZQ & $254.01 \pm 13.68^{\mathrm{abc}}$ & $278.89 \pm 15.32^{\mathrm{ab}}$ & $22.2 \pm 2.24^{\mathrm{abc}}$ & $33.03 \pm 1.60^{\mathrm{abc}}$ & $24.15 \pm 1.92^{\mathrm{abc}}$ & $30.66 \pm 0.88^{\mathrm{abc}}$ \\
\hline
\end{tabular}

Data are expressed as mean $\pm \mathrm{SD}$ of 10 mice in each group. (a) is the level of significance at $P \leq 0.05$ compared with control group. (b) is the level of significance at $P \leq 0.05$ compared with infected untreated group. (c) is the level of significance at $P \leq 0.05$ compared with PZQ treated group.

\subsubsection{Effect on Serum Biochemical Parameters}

Table 4 shows a marked increase in the level of serum IL10 , TNF- $\alpha$, total IgE, ALT and GGT in infected untreated mice accompanied with a significant decrease in the level of serum albumin compared with normal mice. Treatment with PZQ only to $\mathrm{S}$. mansoni infected mice significantly modulated the alteration in the above mentioned biomarkers comparing with infected untreated mice. The prophylactic effect of either of vitamin $\mathrm{E}$, Se, plant extract or the mixture of all supplements in combination with PZQ improved serum biomarkers more than that obtained with either the therapeutic effect of the mentioned supplements or treatment with PZQ only.

Table 4. Prophylactic and therapeutic effect of different supplementations on the levels of serum biochemical parameters

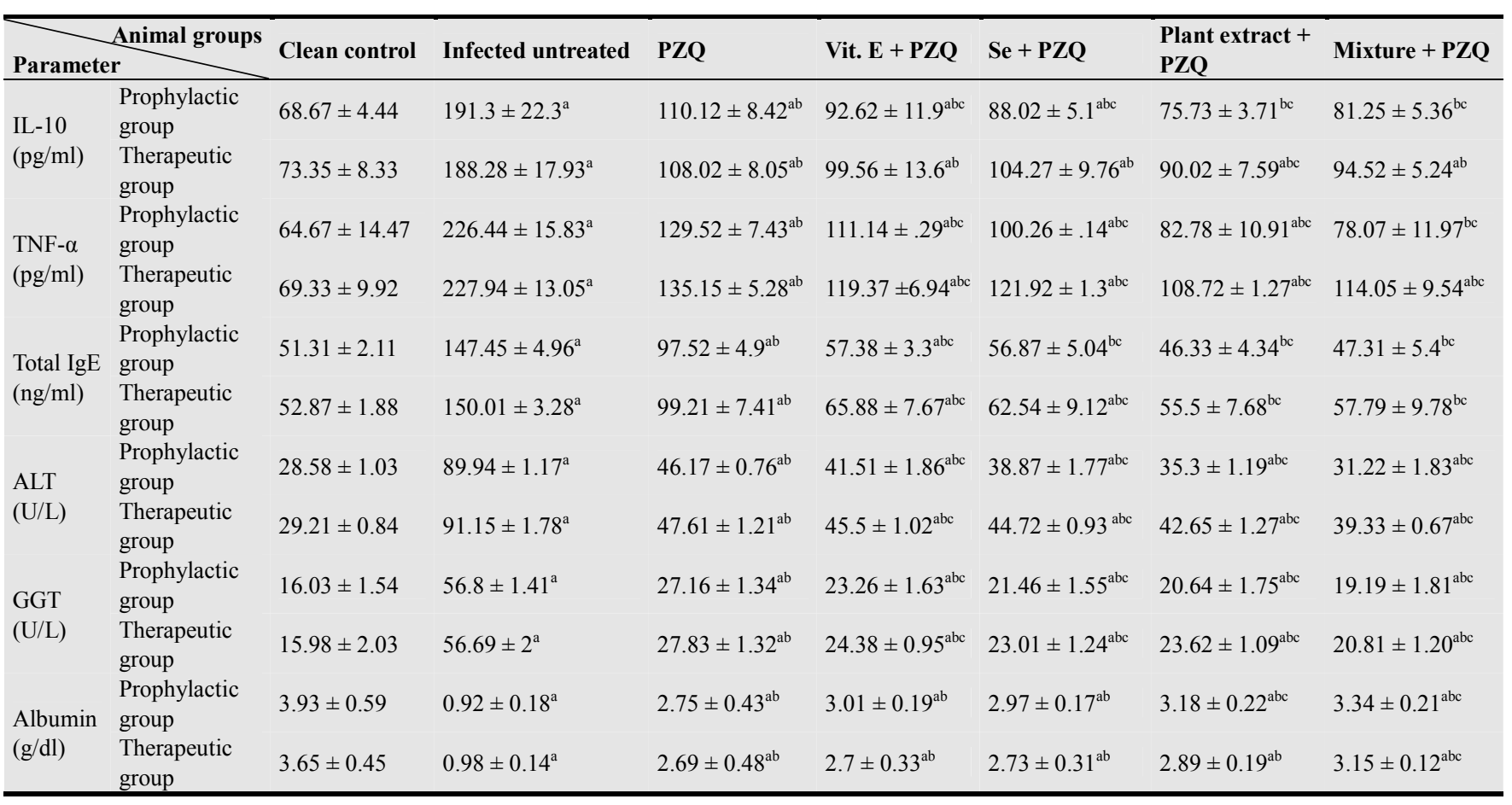

Data are expressed as mean $\pm \mathrm{SD}$ of 10 mice in each group. (a) is the level of significance at $P \leq 0.05$ compared with control group. (b) is the level of significance at $P \leq 0.05$ compared with infected untreated group. (c) is the level of significance at $P \leq 0.05$ compared with PZQ treated 


\section{Discussion}

The efficacy of praziquantel is restricted to the adult stages of the parasite and the mechanism of action of this drug is still not completely understood. Praziquantel is administered to 100 million people every year and less sensitive strains have already been isolated from those peoples. This phenomenon leads to use of large amount of drug administration which become a serious problem [18]. Searching of new drug against schistosomiasis is become the need of time and also recommended by the World Health Organization [19].

The current study demonstrates that oral administration of PZQ to mice harboring S. mansoni have shown potent antischistosomal activity against worm burden however, it showed less effect against egg burden. These findings are in agreement with previous investigators who reported that praziquantel, which is effective against the worm stages of the parasite [20], has only some ovicidal activity against mature schistosomal eggs [21], [22]. The reduction in worm burden with PZQ treatment was previously explained by some authors who illustrated that oral administration of PZQ is rapidly and efficiently absorbed from the intestine and reaches maximum serum levels within 1-2 hours [23]. The mechanism of drug action explained on the basis that the drug is able to increase the permeability of the worm muscle cells to calcium ions which in turn lead to paralysis of the parasite. Hepatic shift is observed within 5 minutes after a single oral dose for infested mice [24].

In a previous study [25] we found that the different supplementations induced a reduction in worm burden as well as ova count. These reductions did not reach the improvement effect of PZQ as a drug alone. Accordingly, the present work aimed to study the combination with PZQ of the different supplementations with PZQ.

The present data showed that the different supplements powered the effect of PZQ either in prophylactic or treated studies.

Reduction in worm burden due to Vit E or Se may be attributed to their antioxidant characteristics. Anti-oxidant supplements are thought to enhance the immunity of the host to attack the parasite and thereby reduce infectious morbidity and protect the mice from pathogens (parasites) to a certain level [26]. Also, Ali [27] proved the importance of antioxidant in the treatment of schistosomal infection and reduction of worm load as well as ova count.

The possible mechanism which may explain the antischistosomal effect of $\mathrm{C}$. quadrangular extract is that it contains active constituents (triterpenes and falvonoid alaglycons) which may have a direct effect on the vitality of schistosome different stages as well as the fecundity of the remaining female adult worms [28]. The plant extract strongly affect the antioxidant system (glutathione concentration, glutathione reductase activity and lipid peroxidation) of adult worms. These parameters have an important role in the protection of the parasite against host oxidant killing [29]. On the other hand El-Naggar [28] also proved that the plant extract affect cholinesterase activity of adult worms leading to its inhabitation and the paralysis of the worm.

The reduction of ova count by the studied supplementation is possibly due to a positive linear relationship between the egg output and the worm burden, where the reduction of the number of worms is correlated with the reduction in the ova count. However, several other factors may also explain such reduction in schistosomal egg count. These factors are a probable diminished fecundity of the worm pairs and an increased rate of egg excretion due to the egg death [30].

Granuloma formation and fibrosis are the major causes of morbidity and mortality in association with schistosomiasis [31]. Previous studies revealed that the intensity of schistosomal infection which is represented by the worm burden and egg count increases the degree of liver fibrosis and granulomatous reaction [32]. This is in agreement with the present histopathological findings of infected untreated mice liver which showed an increased number and diameter of granuloma, total area of infection and extensive fibrous tissue accumulation.

Treatment of infected mice with PZQ improved the histopathological picture of liver. This was ensured by significant diminution in number and diameters of granulomas compared with infected untreated mice. Our results are in line with Chaiworaporn et al. [33] and Botros et al. [34]. The prophylactic treatment of infected animals with the studied agents in combination with PZQ was more effective in improving histopathological liver picture and in reducing number and diameter of granuloma than PZQ alone. While the therapeutic treatment with the studied agents revealed no significant improvement versus the PZQ treated group. These results may indicate that the studied agents have synergistic protective effect with PZQ in improving the pathological manifestation of S. mansoni infection. Also, the treatment with the used supplementation before infection may improve certain immune response against egg antigen and consequentially this affect granuloma count and area of infection. Mahmoud et al. [35] and El-Shenawy et al. [36] found that addition of antioxidants increases the efficacy of PZQ in reducing the granuloma.

Schistosomiasis causes a reduction in the levels of protective endogenous anti-oxidants and increases generation of free radicals [36]. The results of the present work indicated that infection of mice with $\mathrm{S}$. mansoni produced a significant decrease in the non protienized antioxidant, GSH, as well as in the activities of the antioxidant enzymes including GR, TrxR, and CAT accompanied with an elevation in NO and MDA (the end product of LPO) in the livers of infected untreated mice. Our results showed that prophylactic and therapeutic treatment with different supplements (PZQ only as well as the used agents in combination with PZQ) to infected mice induced marked increase in GR, TrxR, CAT activities and GSH level and decreased the deviation in NO as well as MDA in livers when compared to infected untreated mice. The beneficial protective role obtained by the 
studied supplementations in combination with PZQ in modulating the antioxidant and oxidative stress biomarkers of infected mice may be due to this enhance effect which reduces the parasite worms and eggs overload on one hand and the antioxidative properties of the studied supplements on the other hand. These two factors reduce the free radicals induced by the parasite in response to host reaction.

The current investigation revealed that liver fibrosis in response to $\mathrm{S}$. mansoni parasitic infection was documented by a marked increase in hepatic hydroxyproline. Hydroxyproline, is an amino acid characteristic of collagen metabolism and used as a marker to express the extent of liver fibrosis [37]. Similar result was obtained by some authors who emphasized that elevated liver hydroxyproline content was associated with S. mansoni infection [38], [39]. This may be attributed to that $\mathrm{S}$. mansoni egg granulomas contain factors responsible for the elevation of free Lhydroxyproline content in the fibrotic liver [40]. In addition, previous studies reported that reactive oxygen species [41] and products of lipid peroxidation [42] are regarded as triggers that activate hepatic stellate cells, which is the key pathogenic event in liver fibrosis [43]. The current study showed that administration of PZQ down-modulate the alteration in liver hydroxyproline induced by of $\mathrm{S}$. mansoni infection. This is in line with Gnanasekar et al. [39] and ElLakkany et al. [44]. The main explanation for this result is presumed to be a removal of schistosomal worms, and subsequent reduction of egg deposition and granuloma size. As well, using the current agents each alone or their mixture with PZQ successfully reduced the hydroxyproline level in livers of infected mice compared with infected untreated mice documenting their anti-fibrotic effect. The prophylactic treatment with the mixture of all supplementations in combination with PZQ was the most effective one in reducing the level of hepatic hydroxyproline versus the animals treated with PZQ only. This may be attributed to the antioxidative properties of the used agents therefore, it is possible that these agents eliminates the products of oxidative reactions and assists in the immune-mediated destruction of worms and eggs. The improvement in liver hydroxyproline in infected mice treated with either of Vit. E or Se may be attributed to decrease serum hyaluronic acid levels, which correlates with stages of hepatic fibrosis in liver disease [45] and reduction of transforming growth factor- $\beta$ (TGF $\beta$ ) secretion from hepatic stellate cells in the liver [46]. The antifibrotic effect of the used plant extract could be attributed to its active compounds, triterpenes and flavonoid aglycons [28]. Flavonoids and triterpenes exhibited hepato-protective activity, anti-inflammatory and inhibitory effect on liver fibrosis [47].

Previous investigations revealed that non-immunologic and immunologic mechanisms play a central role in liver fibrosis [29]. In line with these investigations, the present study showed that $\mathrm{S}$. mansoni parasitic infection induces the production of inflammatory fibrogenic mediators which ensured by the increase in serum TNF- $\alpha$ level coupled with an elevation in anti-inflammatory cytokine, IL-10. Our finding is in line with different authors [21, 22, 29, 48].

The overproduction of NO in livers in response to parasitic infection, that can induce oxidative stress and inflect tissue injury [49], may be related to the induction of oxidase enzymes as xanthine oxidase (XO) [29] and elevated levels of inflammatory cytokines including TNF- $\alpha$ in response to the activation of T-helper1 (Th1) cells as an early response to parasitic infection [50]. The anti-inflammatory cytokine IL10 is pivotal for the generation of host-protective homeostatic conditions in schistosomiasis [51]. Granuloma development enhances Th immune responses such as IL-10 [52]. Previous studies stated that increasing circulating immunoglobulin (Ig)E level is a humoral response to egg and adult worm antigens suggesting that this mechanism might be involved in hepatic pathological patterns [53]. IgE was reported to have the major role in mast cells stimulation which has a central role in the induction of chronic inflammation [54].

Prophylactic and therapeutic administrations of either Vit $\mathrm{E}$, Se, plant extract or the mixture of all these agents in combination with PZQ treatment as well as the therapeutic treatment with PZQ only pronouncedly down-regulated the levels of the previously mentioned inflammatory mediators parallel with a reduction in the anti-inflammatory one, IL-10. The best results were obtained due to the protective ingestion of infected mice with either of plant extract or the mixture of all supplements in combination with PZQ. These treatments were effective in modulating the deviation in the inflammatory as well as the anti-inflammatory biomarkers with respect to infected animals treated with PZQ only. The improvement in the inflammatory and anti-inflammatory mediators may be attributed to the improved parasitological parameters by the used agents as well as the anti-oxidant parameters as mentioned before.

In consistent with several studies, the present study showed that the inflammatory reactions induced in livers of S. mansoni infected mice are ensured by marked increase in serum GGT and ALT levels and a decrease in albumin level $[29,55]$. The increase of such enzymes in serum may be due to the destruction of hepatocytes by the action of toxins of the parasite eggs leading to their release into the circulation [56]. The decrease in serum albumin may be due to its glycation by glucose forming fructosamine together with reduction in its synthesis by damaged liver [29].

Oral administration of the studied supplements in combination with PZQ, effectively ameliorated the above serum marker of infected mice. This positive response may be attributed to their ability to protect and stabilize cellular membranes permeability and integrity. This protective action of the used micronutrients is supported by Khalifa et al. [57] and Soudani et al. [58].

In conclusion, the combination of the studied supplements (vitamin $\mathrm{E}, \mathrm{Se}$, chloroform extract of C. quadrangular as well as their mixture) and PZQ improved the efficiency of PZQ on one hand. On the other hand, studied agents are very effective in attenuating the oxidative insult associated with S. mansoni infection. 


\section{References}

[1] Liu LX, Qiong C, Fan XL: Recent Advances in Antischistosomal Drugs and Agents. Mini Rev Med Chem 19; 2013: Epub ahead of print.

[2] Chai JY: Praziquantel treatment in trematode and cestode infections: an update. Infect Chemother 45(1); 2013: 32-43.

[3] da Silva IM, Thiengo R, Conceição MJ, Rey M, Lenzi HL, Filho EP, Ribeiro PC: Therapeutic failure of praziquantel in the treatment of Schistosoma haematobium infection in Brazilians returning from Africa. Mem Inst Oswaldo Cruz, Rio de Janeiro 100 (4); 2005: 445- 449.

[4] Gonnert R, Andrews P: Praziquantel, a new broad-spectrum anti-schistosomal agent. Zeitschrift für Parasitenkunde 52; 1977: $129-150$.

[5] El-Demerdash FM: Antioxidant effect of vitamin E and selenium on lipid peroxidation, enzyme activities and biochemical parameters in rats exposed to aluminium. J.Trace Elem Med Biol 18; 2004: 113-121.

[6] Holland JC, Pellegrino J, Cozinelli F: Infection of mice with cercariae, schistosomula of S. mansoni by intravenous and subcutaneous routes. Rev Inst Med Trop Sào Paulo 16; 1974: 132-134.

[7] Smithers SE, Terry RJ: The infection of laboratory hosts with cercariae of S. mansoni and recovery of worms. J Parasitol 55; 1965: 695-700.

[8] Kamel IA, Cheever AW, Elwi A, Mosimann JE, Danner R: S. mansoni and S. haematobium infection in Egyptian technique for recovery of worms at necropsy. Am J Trop Med Hyg 26; 1977: 696- 701

[9] Hirsch C, Zouain CS, Alves JB, Goes AM: Induction of protective immunity and modulation of granulomatous hypersensitivity in mice using PIII, an anionic fraction of Schistosoma mansoni adult worm. Parasitol 115; 1997: 21-28.

[10] Mahmoud AAF, Warren KS: Anti-inflammatory effect of tartaremetic and niridazole suppression of schistosoma egg granuloma. J Immunol 112; 1974: 222-228.

[11] Erden M, Bor NM: Changes of reduced glutathion, glutathion reductase, and glutathione peroxidase after radiation in guinea pigs. Biochem Med 31; 1984: 217-227.

[12] Holmgren A, Björsnstedt M: Thioredoxin and thioredoxin reductase. Methods Enzymol 252; 1995: 199-208.

[13] Lubinsky S, Bewley GC: Genetics of catalase in Drosophila melanogaster: Rates of synthesis and degradation of the enzyme in flies aneuploid and euploid for the structural gene. Genetics 91; 1979: 723-742.

[14] Moron MS, Depierre JW, Mannervik B: Levels of glutathione, glutathione reductase and glutathione S-transferase activities in rat lung and liver. Biochim Biophys Acta 582; 1979: 67-78.

[15] Jamall IS, Finelli VN, QueHee SS: A simple method to determine nanogram levels of 4-hydroxyproline in biological tissues. Anal Biochem 112; 1981: 70-75.

[16] Moshage H, Kok B, Huizenga JR, Jansen PL: Nitrite and nitrate determinations in plasma: a critical evaluation. ClinChem 41; 1995: 892-896.
[17] Ruiz-Larrea MB, Leal AM, Liza M, Lacort M, de Groot H: Antioxidant effects of estradiol and 2-hydroxyestradiol on iron-induced lipid peroxidation of rat liver microsomes. Steroids 59; 1994: 383-388.

[18] Doenhoff M, Cioli D, Utzinger J: Praziquantel: mechanisms of action, resistance and new derivatives for schistosomiasis. CurrOpin Infect Dis 21; 2008: 659-667.

[19] Stothard JR, Chitsulo L, Kristensen TK Utzinger J: Control of schistosomiasis in sub-Saharan Africa: progress made, new opportunities and remaining challenges. Parasitol 136 (13); 2009:1665-75.

[20] WHO: model prescribing information: drugs used in parasitic diseases. 2nd ed. Geneva; World Health Organization 1995.

[21] Helmy M, Mahmoud S, Fahmy Z: Schistosoma mansoni: Effect of dietary zinc supplement on egg granuloma in Swiss mice treated with praziqantel. ExpParasitol 122; 2009: 310 317.

[22] Ibrahim RB, Hendawy MA, Ali E, Hedaya MS, Nosseir MMF: Effect of Diphenyl Dimethyl Bicarboxylate and Dexamethasone on Immunological and parasitological parameters in murine schistosomiasis mansoni. J Am Sci 6 (5); 2010: 10- 18.

[23] El-Ridy MS, Mostafa DM, Mahmoud MR: Optimising liposome-encapsulated praziquantel formulations for treating and overcoming resistant isolated Schistosoma mansoni. Bull NRC Egypt 30 (6); 2005: 531- 544.

[24] Wu GY, Halim MH: Schistosomiasis progress and problems. World J Gastoenterol 6 (1); 2000: 12- 19.

[25] Shadia M. Kadry, Azza M. Mohamed, Ebtehal M. and Dalia B. Fayed: Influence of some micronutrients and Citharexylum quadrangular extract against liver fibrosis in Schistosoma mansoni infected mice. African Journal of Pharmacy and Pharmacology 7(38);2013: 2628-2638.

[26] Farrag E, Maghraby A, Foda DS: Chemoprophylactic effect of selenium and vitamin $\mathrm{E}$ against Schistosoma mansoni infected mice. Egypt Pharm J 4; 2005: 487-497.

[27] Ali HF: Evaluation of antioxidants effect of Citrus reticulate in Schistosomamansoni infected mice. Trends Med Res 2(1); 2007: 37-43.

[28] El-Naggar DM: Antibilharzial study of some extracts from Citharexylum quadrangular Jacq. Ph. D. Thesis, Fac Pharm Girls, Al- AzharUniv; 2007: 177pp.

[29] Mohamed AM, Mahmoud SS, Farrag AA: Influence of Sativa seeds against liver fibrosis and consequence complications in murine schistosomiasis. Int J Biotechnol Biochem 4; 2008: 325-346.

[30] Riad NHA, Taha HA, Mahmoud YI: Effects of garlic on albino mice experimentally infected with Schistosoma mansoni: A parasitological and ultrastructural study. Trop Biomed 26 (1); 2009: 40-50.

[31] Melo CM, de Lima AL, Beltrão EI, Cavalcanti CC, de MeloJúnior MR, Montenegro SM, Coelho LC, Correia MT, Carneiro-Leão AM: Potential effects of Cramoll 1,4 lectin on murine schistosomiasis mansoni. Acta Trop 118 (2); 2011: 152-158. 
[32] El-Lakkany NM, Seif El-Din SH, Badawy AA, Ebeid FA: Effect of artemether alone and in combination with grape fruit juice on hepatic drug-metabolizing enzymes and biochemical aspects in experimental Schistosoma mansoni. Int J Parasitol 34; 2004: 1405-1412.

[33] Chaiworaporn R, Maneerat Y, Rojekittikhun W, Ramasoota P, Janecharut T, Matsuda H, Kitikoon V: Therapeutic effect of subcurative dose praziquantel on Schistosoma mansoni infected mice and resistance to challenge infection after treatment. Southeast Asian J Trop Med Public Health 36 (4); 2005: 846-852.

[34] Botros S, Hammam OA, El-lakkany NM, SeifEi-Din SH, Ebeid FA: Schistosma haematibium (Egyptian strain): Rate of development and effect of praziquantel treatment $\mathrm{J}$ Parasitol 94 (2); 2008: 386- 304

[35] Mahmoud MR, Zheiry MM, Nosseir MM: Effect of combined chemotherapy and anti-inflammatory drugs on murine schistosomiasis. ArZneiMittel-ForsChing 53 (4); 2002: 294301.

[36] EL-Shenawy NS, Soliman MFM, Reyad SI: The effect of antioxidant properties of aqueous garlic extract and Nigella sativa as anti-schistosomiasis agents in mice. Rev Inst Med Trop Sao Paulo 50; 2008: 29-36.

[37] Souza ALS, Roffe E, Pinho V, Souza DG, Silva AF, Russo RC, Guabiraba R, Pereira CAJ, Carvalho FM, Barsante MM, Oliveira RC, Fraga LAO, Correa DN, Teixeira MM: Potential role of the chemokine macrophage inflammatory protein $1 \alpha$ in human and experimental schistosomiasis. Infect Immun 73; 2005: 2515-2523.

[38] Loebermann M, Sombetzki M, Langner C, Fuchsbichler A, Gumhold J, Silbert D, Riebold D, Holtfreter M, Fickert P, Nizze H, Trauner M, Reisinger EC: Imbalance of pro- and antifibrogenic genes and bile duct injury in murine Schistosoma mansoni infection-induced liver fibrosis. Trop Med Int Health 14; 2009: 1418-1425.

[39] El-Lakkany NM, Hammam OA, El-Maadawy WH, Badawy A, Ain-Shoka AA, Ebeid FA: Anti-inflammatory/anti-fibrotic effects of the hepatoprotective silymarin and the schistosomicidepraziquantel against Schistosomamansoniinduced liver fibrosis. Parasit Vectors 5; 2012: 9.

[40] Potter JJ, Tankesley LR, Mezey E: Influence of leptin in the development of hepatic fibrosis produced in mice by Schistosoma mansoni infection and by chronic carbon tetrachloride administration. J Hepatol 38; 2003: 281-288.

[41] Galli A, Svegliati-Baron G, Ceni E, Milani S, Ridolfi F, Salzano R, Tarocchi M, Grappone C, Pellegrini G, Benedetti A, Surrenti C, Casini A. Oxidative stress stimulates proliferation and invasiveness of hepatic stellate cells via a MMP2-mediated mechanism. Hepatol 41; 2005: 1074-1084.

[42] George J, Pera N, Phung N, Leclercq I, Yun Hou J, Farrell G: Lipid peroxidation, stellate cell activation and hepatic fibrogenesis in a rat model of chronic steatohepatitis. J Hepatol 39; 2003: 756-764.

[43] Gutierrez-Ruiz MC, GOmez-Quiroz LE: Liver fibrosis: searching for cell model answers. Liver Int 27; 2007: 434 439.

[44] Gnanasekar M, Salunkhe AM, Mallia AM, He YX, Kalyanasundaram R: Praziquantel affects the regulatory myosin 1Light chain of Schistosoma mansoni. Antimicrob. Agents Chemother 53 (3); 2009: 1054-1060.
[45] Mezey E, Liu X, Potter J: The combination of selenium and vitamin $\mathrm{E}$ inhibits type I collagen formation in cultured hepatic stellate cells. Biol Trace Elem Res 140; 2011: 82-94.

[46] Soylu AR, Aydogdu N, Basaran UN, Altaner S, Tarcin O, Gedik N, Umit H, Tezel A, Dokmeci G, Baloglu H, Ture M, Kutlu K, Kaymak K: Antioxidants vitamin E and C attenuate hepatic fibrosis in biliary-obstructed rats. World J Gastroenterol 12 (42); 2006: 6835-41.

[47] Wang X, Ikejima K, Kon K, Arai K, Aoyama T, Okumura K, Abe W, Sato N, Watanabe S: Ursolic acid ameliorates hepatic fibrosis in the rat by specific induction of apoptosis in hepatic stellate cells. J Hepatol 55; 2011: 379-387.

[48] El-Lakkany N, Seif el-Din S, Ebeid F: The use of pentoxifylline as adjuvant therapy with praziquantel down regulates profibrogenic cytokines, collagen deposition and oxidative stress in experimental schistosomiasis mansoni. ExpParasitol 129; 2011: 152-157.

[49] Harrison R: Structure and function of xanthine oxidoreductase: where are we now? Free Radic Biol Med 33; 2002: 774-797.

[50] James SL, Cheever AW, Caspar P, Wynn TA: Inducible nitric oxide synthase-deficient mice develop enhanced type 1 cytokine-associated cellular and humoral immune response after vaccination with attenuated Schistosoma mansoni cercariae but display partially reduced resistance. Infect Immun 66; 1998: 3510-3518.

[51] Hoffmann KF, Cheever AW, Wynn TA: IL-10 and the dangers of immune polarization excessive type 1 and type 2 cytokine responses induce distinct forms of lethal immunopathology in murine schistosomiasis. J Immunol 164; 2000: 6406- 6416.

[52] Ritter M, Gross O, Kays S, Ruland J, Nimmerjahn F, Saijo S, Tschopp J, Layland LE, Prazeres da Costa C: Schistosoma mansoni triggers Dectin-2, which activates the Nlrp3 inflammasome and alters adaptive immune responses. ProcNatlAcadSci USA. 107(47); 2010: 20459-64.

[53] Silva LM, Oliveira AS, dos-Santos RR, Andrade ZA, Soares MBP: Comparison of immune responses of Schistosoma mansoni-infected mice with distinct chronic forms of the disease. ActaTropica 91; 2004: 189-196.

[54] Jayapal M, Tay HK, Reghunathan R, Zhi L, Chow KK, Rauff $\mathrm{M}$, Melendez AJ: Genome-wide gene expression profiling of human mast cells stimulated by IgE or FceRI-aggregation reveals a complex network of genes involved in inflammatory responses. BMC Genomics 7; 2006: 210-227.

[55] Allam G: Vasoactive intestinal peptide inhibits liver pathology in acute murine schistosomiasis mansoni and modulates IL10, IL-12 and TNF- $\alpha$ production. Immunobiol 212; 2007: 603-612.

[56] Cheever AW, Anderson LA: Rate of destruction of Schistosomamansoni eggs in tissues of mice. Am J Trop Med Hyg 20; 1971: 62-68.

[57] Khalifa TI, El-Gendi OD, Ammar HA, El-Naggar DM: Iridoid Glycosides from Citharexylum quadrangular. Asian J Chem 14; 2002: 197-202.

[58] Soudani N, Ben Amara I, Sefi M, Boudawara T, Zeghal N: Effects of selenium on chromium (VI)-induced hepatotoxicity in adult rats. Exp Toxicol Pathol 63; 2011: 541-548. 